\title{
Correlation of morphological patterns of nucleoli in alveolar macrophages with HLA-DR antigen expression in sarcoidosis
}

Pulmonary the Stadt Wien-Lainz, A-1130 Vienna W Popp

Histologisch-

Embryologisches

Institut, Universität

Wien, A-1090 Vienna,

Austria

F J Wachtler

Reprint requests to:

Dr W Popp

Accepted 22 August 1991

W Popp, F J Wachtler

\begin{abstract}
Background Alveolar macrophages from patients with sarcoidosis express increased quantities of HLA-DR during activation. Because silver staining has been described as a sensitive indicator of cellular activity a study was performed to examine whether it relates to HLA-DR antigen expression.

Methods The relation between silver staining patterns of nucleoli and HLA-DR antigen expression was examined in alveolar macrophages collected by bronchoalveolar lavage from 11 patients with pulmonary sarcoidosis and 11 control subjects.

Results The mean (SD) number of silver stained protein dots associated with the nucleolar organiser regions (AgNORs) was significantly higher in alveolar macrophages from patients with sarcoidosis $(7.5(1.5))$ than in those from control subjects $(5 \cdot 6(0.6))$. The number of silver stained dots in alveolar macrophages correlated significantly with the intensity and the density of HLA-DR antigen expression in the patients with sarcoidosis.

Conclusion Silver staining may be a sensitive tool for the investigation of the biological cell activity of alveolar macrophages in sarcoidosis.
\end{abstract}

Silver staining of nucleoli was first reported in 1899. ${ }^{1}$ A local and functional relation was found between certain chromosomes and nucleoli; ${ }^{2}$ the regions thus identified have been called nucleolar organiser regions (NORs). ${ }^{34}$ These are regions of acrocentric chromosomes containing major ribosomal RNA (rRNA) genes and NOR associated proteins, which result from transcription ${ }^{5-8}$ and can be seen with silver staining. Previous studies have related the amount and distribution of NOR associated silver stained proteins with cellular activity in vitro $^{9-13}$ and in vivo. ${ }^{14-16}$ The silver stained dots are usually called AgNORs, and should not be confused with the number of transcriptionally active NORs in the cell. Wide discrepancies have been observed between the number of silver stained dots and the number of NOR chromosome genomes. ${ }^{101718}$ In many studies silver staining has been found to be helpful in the diagnosis of malignancy and as a sensitive indicator of cellular activity. ${ }^{619-21}$

Alveolar macrophages in patients with sarcoidosis are described as being highly activated and are concerned in an active immunological process. ${ }^{22-26}$ They have been shown to express increased quantities of HLA-DR antigen during activation. The fact that silver staining is also a sensitive marker of cellular activation prompts the question of whether silver staining is correlated with HLA-DR expression, an immunological feature of activated alveolar macrophages. The object of our investigation was to compare silver staining and HLA-DR expression in alveolar macrophages obtained by bronchoalveolar lavage from patients with sarcoidosis and from healthy control subjects.

Methods

SUBJECTS

We studied 11 patients with pulmonary sarcoidosis (confirmed by transbronchial lung biopsy) and 11 healthy control subjects. Consecutive patients with sarcoidosis seen in the pulmonary unit were included provided that they had not been treated and were nonsmokers at the time of the investigation; two patients were ex-smokers who had smoked less than 10 cigarettes a day and stopped at least two years before the investigation. The control subjects were healthy non-smokers, three of whom had smoked less than 10 cigarettes a day but had stopped at least three years before the investigation. The diagnosis of sarcoidosis was confirmed by transbronchial lung biopsy.

\section{BRONCHOALVEOLAR LAVAGE}

All subjects underwent bronchoalveolar lavage, ${ }^{27}$ which was performed with a fibreoptic bronchoscope (Olympus B10) after local anaesthesia with $2 \%$ xylocaine. One hundred millilitres of isotonic warmed saline were instilled into the middle lobe in $20 \mathrm{ml}$ aliquots and recovered by gentle aspiration. The fluid was collected into siliconised glass tubes and processed immediately at $4^{\circ} \mathrm{C}$.

\section{HLA-DR ANALYSIS}

Cells were counted in a haemocytometer. Cytocentrifuge cell preparations were made for May-Grünwald-Giemsa and silver staining. Differential cell counts were performed on 400 cells and individual counts were given as per- 
Table 1 Data on the subjects and results of analysis of bronchoalveolar cells (mean (SD) values)*

\begin{tabular}{|c|c|c|c|}
\hline & $\begin{array}{l}\text { Sarcoidosis } \\
(n=11)\end{array}$ & $\begin{array}{l}\text { Controls } \\
(n=11)\end{array}$ & $p$ \\
\hline $\begin{array}{l}\text { Age (years) } \\
\operatorname{Sex}(M / F)\end{array}$ & $\begin{array}{l}47 \cdot 5(8 \cdot 2) \\
2 / 9\end{array}$ & $\begin{array}{l}45 \cdot 6(9 \cdot 9) \\
2 / 9\end{array}$ & \\
\hline $\begin{array}{l}\text { Chest radiograph stage } \dagger \\
\text { I } \\
\text { II } \\
\text { III }\end{array}$ & $\begin{array}{l}3 \\
6 \\
2\end{array}$ & $\begin{array}{l}0 \\
0 \\
0\end{array}$ & \\
\hline $\begin{array}{l}\text { Respiratory values (\% pred) } \\
\text { VC } \\
\text { FEV } \\
\text { TLC } \\
\text { TLCO } \\
\text { TLCO/VA }\end{array}$ & $\begin{array}{r}87 \cdot 9(19 \cdot 9) \\
82 \cdot 9(17 \cdot 0) \\
100 \cdot 5(15 \cdot 1) \\
78 \cdot 2(12 \cdot 1) \\
73 \cdot 4(11 \cdot 1)\end{array}$ & $\begin{array}{c}97.6(11 \cdot 7) \\
95 \cdot 5(13.4) \\
110.8(8.3) \\
96 \cdot 2(13.5) \\
96 \cdot 3(14.5)\end{array}$ & $\begin{array}{l}\text { NS } \\
\text { NS } \\
<0.05 \\
<0.05 \\
<0.01\end{array}$ \\
\hline $\operatorname{ACE}(\mathrm{U} / \mathrm{ml})$ & $23 \cdot 8(8 \cdot 6)$ & $13 \cdot 0(4 \cdot 3)$ & $<0.05$ \\
\hline Lavage fluid total cell count $\left(\times 10^{6}\right)$ & $16.9(9 \cdot 4)$ & $10 \cdot 1(2 \cdot 5)$ & $<0.05$ \\
\hline $\begin{array}{l}\text { Differential count }(\%) \\
\text { Alveolar macrophages } \\
\text { Lymphocytes } \\
\text { Neutrophil granulocytes } \\
\text { Eosinophil granulocytes }\end{array}$ & $\begin{array}{c}52 \cdot 6(23 \cdot 8) \\
45 \cdot 0(25 \cdot 7) \\
2 \cdot 0(2 \cdot 6) \\
0 \cdot 4(0 \cdot 4)\end{array}$ & $\begin{array}{r}88.9(7 \cdot 2) \\
8 \cdot 6(7 \cdot 2) \\
1.0(1 \cdot 0) \\
0 \cdot 4(0 \cdot 7)\end{array}$ & $\begin{array}{l}<0.05 \\
<0.05 \\
\text { NS } \\
\text { NS }\end{array}$ \\
\hline $\begin{array}{l}\text { Alveolar macrophages } \\
\% \text { HLA-DR positive } \\
\text { Cell diameter }(\mu \mathrm{m}) \\
\text { Nuclear diameter }(\mu \mathrm{m}) \\
\text { No of IF units } \\
\text { Density of IF units } \\
\text { No of silver positive dots/nucleus }\end{array}$ & $\begin{array}{c}97.8(1 \cdot 2) \\
24.5(1.6) \\
9.0(0 \cdot 6) \\
183.6(42 \cdot 0) \\
0.0972(0.0191) \\
7.5(1.5)\end{array}$ & $\begin{array}{l}96 \cdot 5(2 \cdot 5) \\
23 \cdot 3(1 \cdot 3) \\
9 \cdot 1(0 \cdot 4) \\
122 \cdot 0(29 \cdot 9) \\
0 \cdot 0730(0 \cdot 0212) \\
5 \cdot 6(0 \cdot 6)\end{array}$ & $\begin{array}{l}\text { NS } \\
\text { NS } \\
\text { NS } \\
<0.05 \\
<0.05 \\
<0.01\end{array}$ \\
\hline
\end{tabular}

*Differences between the sarcoidosis group and the control group analysed by the Kolmogoroff-Smirnoff test.

† Sarcoidosis stage: I-bilateral hilar lymphadenopathy; II-I + infiltrates; III-lung fibrosis.

VC-vital capacity; $\mathrm{FEV}_{1}$ - forced expiratory volume in one second; TLC-total lung capacity; TLCO-transfer factor for carbon monoxide; TLCo/VA-transfer factor for carbon monoxide per alveolar volume; $\mathrm{ACE}$ - serum angiotensin converting enzyme; IF-immunofluorescence units.
SILVER STAINING AND NUCLEOLAR MORPHOLOGY After the slides had been fixed in phosphate buffered formalin silver staining was done with freshly prepared reagent: $2 \mathrm{~g}$ gelatin dissolved in a $1 \%$ aqueous solution of formic acid was mixed with a $50 \%$ aqueous solution of silver nitrate in a proportion of $1: 2 .^{20}$ The cytocentrifuge cell preparations were incubated in this reagent for 30 minutes at room temperature under dark room conditions. The slides were then washed thoroughly with deionised water, dehydrated in xylene, and mounted in Entelan. The number of silver stained dots (AgNORs) per nucleus was determined for each subject from 400 alveolar macrophages without knowledge of the diagnosis.

\section{ANALYSIS}

The Kolmogoroff-Smirnoff test was used to compare the two groups and Spearman's rank correlation to study the influence of cellular changes and HLA-DR expression on the AgNOR counts. A p value below 0.05 was considered significant. ${ }^{28}$

\section{Results}

Details of the subjects and the results are shown in table 1. Patients with pulmonary sarcoidosis had higher total cell counts, lower percentages of alveolar macrophages, and higher percentages of lymphocytes. The proportion of HLA-DR positive alveolar macrophages was above $90 \%$ in both groups. The intensity of immunofluorescent staining of HLA-DR antigen varied considerably but was significantly higher in the patients with sarcoidosis. The number of AgNORs within the nuclei of alveolar macrophages was significantly higher in the subjects with sarcoidosis than in the control subjects (figure).

There was a significant positive correlation between the number of AgNORs and both the intensity of immunofluorescent staining of HLA-DR antigen and the density of HLA-DR antigen expression on alveolar macrophages in the patients with sarcoidosis (table 2). The trend was in the same direction in control subjects but was not significant. The number of AgNORs did not correlate with the percentages of DR positive alveolar macrophages, total cell size, or nuclear size. cent staining was referred to as immunofluorescence (IF) "units." Total cell size and nuclear size were measured, and the density of immunofluorescence was calculated from the results of immunofluorescent staining and cell size. $^{25}$

\section{Discussion}

Silver staining of alveolar macrophages

\section{Left: Alveolar} macrophages collected from a patient with sarcoidosis obtained by bronchoalveolar lavage showing several silver stained dots within the nucleolus. Right: Alveolar macrophages from a control subject showing only a few silver stained dots within the nucleolus.

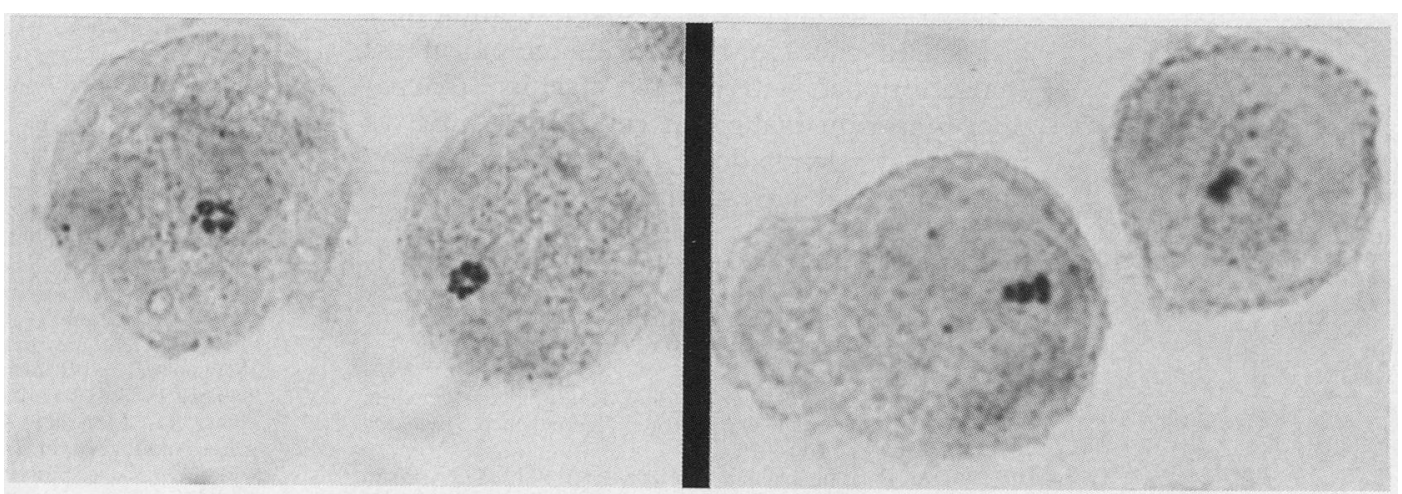


Table 2 Spearman's rank correlation analysis*

\begin{tabular}{llc}
\hline & \multicolumn{2}{l}{$\begin{array}{l}\text { Silver stained dots (AgNORs)/ } \\
\text { nucleus }\end{array}$} \\
\cline { 2 - 3 } & $r$ & $p \dagger$ \\
\hline Sarcoidosis group & & \\
Mean \% of HLA-DR positive cells & 0.00235 & $\mathrm{NS}$ \\
Mean cell diameter & 0.47273 & $\mathrm{NS}$ \\
Mean nuclear diameter & 0.24146 & $\mathrm{NS}$ \\
Mean IF units & 0.87016 & $<0.001$ \\
Mean density of IF units & 0.64546 & $<0.05$ \\
Control group & & \\
Mean \% of HLA-DR positive cells & -0.01839 & $\mathrm{NS}$ \\
Mean cell diameter & -0.11818 & $\mathrm{NS}$ \\
Mean nuclear diameter & 0.51618 & $\mathrm{NS}$ \\
Mean IF units & 0.41914 & $\mathrm{NS}$ \\
Mean density of IF units & 0.35455 & NS \\
\hline
\end{tabular}

*Correlations of silver stained dots with HLA-DR antigen expression on alveolar macrophages are given for patients with sarcoidosis and controls.

†Spearman's rank test.

IF-immunofluorescence.
3 McClintock B. The relation of a particular chromosomal element to the development of the nucleoli in Zea mays. $Z$ Zellforsch 1934;21:294-328.

4 Schwarzacher HG, Wachtler F. Nucleolus organizer regions and nucleoli. Hum Genet 1983;63:89-99.

5 Bloom SE, Goodpasture C. An improved technique for selective silver-staining of nucleolar organizer regions in human chromosomes. Hum Genet 1976;34:199-206.

6 Evans HJ, Buckland RA, Pardue ML. Location of genes coding for $18 S$ and $28 S$ ribosomal RNA in the human genome. Chromosoma 1974;48:405-26.

7 Ploton D, Menager M, Jeannesson P, Himber G, Pigeon F, Adnett JJ. Improvement in the staining and in the visualisation of the argyrophilic proteins of the nucleolar organizer region at the optical level. Histochem $J 1986$ 18:5-14.

8 Smetana $\mathrm{K}$, Busch $\mathrm{H}$. The nucleolus and nucleolar DNA. In: Busch $\mathrm{H}$, ed. The cell nucleus. Vol. 1. New York: Academic Press, 1974:75-147.

9 Popp W, Wachtler F. Changes in nucleolar structure, number and size in cellular activation and inactivation Cell Tissue Res 1983;234:377-88.

10 Pössnerova V, Smetana K. The morphology of lymphocytes in peripheral human blood after short term cultivation in vitro. Folia Morphol (Praha) 1966;14:240-4.

11 Trere D, Pession A, Derenzini M. The silver stained proteins of interphasic nucleolar organizer regions as a parameter of cell duplication rate. Exp Cell Res 1989; 184:131-7.

12 Wachtler F, Ellinger A, Schwarzacher HG. Nucleolar changes in human PHA-stimulated lymphocytes. Cell Tissue Res 1980;213:351-60.

13 Wachtler F, Popp W, Schwarzacher HG. Structural changes in nucleoli during inhibition of protein- and RNA-biosynthesis. Cell Tissue Res 1987;247:583-9.

14 Ayres JG, Crocker J, Skilbeck NQ. Differentiation of malignant from normal and reactive mesothelial cells by the argyrophil technique for nucleolar organiser regions associated proteins. Thorax 1988;43:366-70.

15 Dervan PA, Gilmartin LG, Loftus BM, Carney DN. Breast carcinoma kinetics. Argyrophilic nucleolar organizer region counts correlate with Ki67 scores. Am J Pathol 1989;92:401-7.

16 Egan MJ, Crocker J. Evaluation of nucleolar organiser regions in pulmonary pathology. Thorax $1990 ; 45 \cdot 225-32$.

17 Wachtler F, Hopman AHN, Wiegant J, Schwarzacher HG. On the position of nucleolus organizer regions (NORs) in interphase nuclei. Exp Cell Res 1986;167:227-40.

18 Wachtler F, Roubicek C, Schedle A, Mosgöller W, Bretis G, Schwarzacher HG. Nucleolus organizer regions in human lymphocytes as studied with premature chromosome condensation. Hum Genet 1990;84:244-8.

19 Crocker J, Ayres J, McGovern J. Nucleolar organiser regions in small cell carcinoma of the bronchus. Thorax 1987;42:972-5.

20 Crocker J, Nar P. Nucleolar organizer regions in lymphomas. J Pathol 1987;151:111-8.

21 Leong ASY, Gilham P. Silver staining of nucleolar organizer regions in malignant melanoma and melanotic nevi. Hum Pathol 1989;20:257-62.

22 Campbell DA, du Bois RM, Butcher RG, Poulter LW. The density of HLA-DR antigen expression on alveolar macrophages is increased in pulmonary sarcoidosis. Clin Exp Immunol 1986;65:165-71.

23 Haslam PL, Parker DJ, Townsend PJ. Increases in HLA $\mathrm{DQ}, \mathrm{DP}, \mathrm{DR}$, and transferrin receptors on alveolar macrophages in sarcoidosis and allergic alveolitis compared with fibrosing alveolitis. Chest 1990;97:651-1.

24 Hunninghake GW. Release of interleukin-1 by alveolar macrophages of patients with active pulmonary sarcoidosis. Am Rev Respir Dis 1984;129:569-72.

25 Popp W, Braun O, Zwick H, Rauscher H, Ritschka L. Increased expression of HLA-DR antigen on alveolar macrophages in pulmonary diseases. Virchows Archiv $A$ Pathol Anat 1989;414:393-7.

26 Thomas PD, Hunninghake GW. Current concepts of the pathogenesis of sarcoidosis. Am Rev Respir Dis 1987; 135:747-60.

27 Reynolds HY. Bronchoalveolar lavage. Am Rev Respir Dis 1987;135:250-63.

28 Sachs L. Angewandte Statistik. 6th-ed. Berlin: Springer, 1984:228-30, 308-12.

29 Goessens G. Nucleolar structure. Int Rev Cytol 1984; 87:107-58.

30 Mirre C, Knibiehler B. Quantitative ultrastructural analysis of fibrillar centers in the mouse. Correlation of their number and volume with nucleolar organizer-activity. number and volume with nu

31 Janeway CA Jr, Bottomly K, Babich J, Conrad P, Conzen S Jones B, et al. Quantitative variation in Ia antigen expression plays a central role in immune regulation. Immunology Today 1984;5:99-105.

32 Poulter $\mathbf{L W}$. Antigen presenting cells in situ: their identification and involvement in immunopathology. Clin Exp Immunol 1983;53:513-20.

1 Ruzicka V. Zur Geschichte und Kenntnis der feineren Structur der Nucleolen centraler Nervenzellen. Anat Anz 1899;16:557-63.

2 Heitz E. Die Ursache der gesetzmäßigen Zahl, Lage, Form und Größe pflanzlicher Nucleolen. Planta 1931;12: 775-884.
Reinherz EI Morimoto C, Penta AC, Schlossmann SF Subpopulations of the T4 + inducer $T$ cell subsets in man: evidence for an amplifier population-pneferentially expressing Ia antigen upon activation. J Immunol 1981;126: 67-72. 